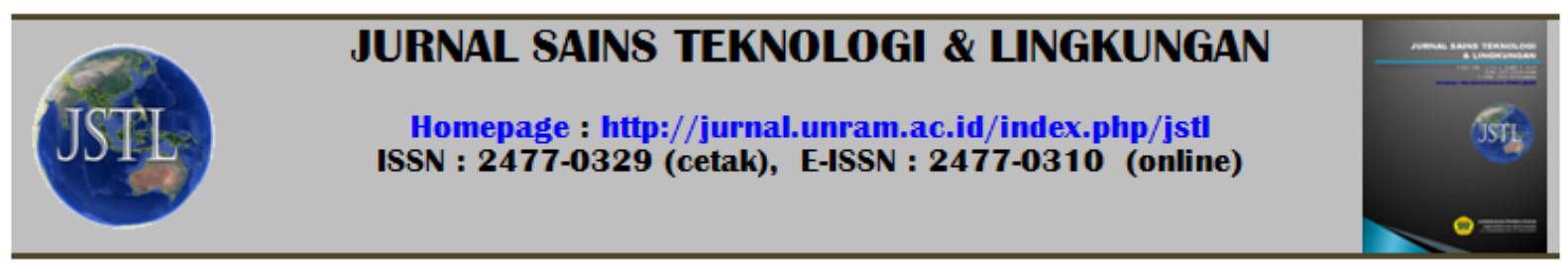

\title{
KERUSAKAN LAHAN UNTUK PRODUKSI BIOMASSA DI KABUPATEN LOMBOK BARAT
}

$\left.{ }^{1}\right)$ Bustan, $\left.{ }^{1}\right)$ M. Dahlan, $\left.{ }^{1}\right)$ Joko Priyono, dan $\left.{ }^{1}\right)$ B. Dewi Krisnayanti $\left.{ }^{1}\right)$ Fakultas Pertanian Univerisitas Mataram

\begin{tabular}{l}
\hline Kata kunci: \\
\hline Kerusakan \\
Lahan, \\
Biomassa
\end{tabular}
Abstrak
Tujuan penelitian ini adalah mengetahui kondisi (tingkat kerusakan) lahan di Kabupaten Lombok Barat, khususnya yang berkaitan dengan kemampuan lahan dalam memproduksi biomasa, Penelitian dilakukan dengan menggunakan metode survei. Penelitian itu diawali dengan pembuatan peta dasar (skala 1:50.000) menggunakan citra satelit Alos Avnir-2, sebagai peta sementara, kemudian dioverlay dengan peta topografi dan landuse. Selanjutnya, dilakukan penentuan titik sample (sampling site), pengecekan kondisi lahan riil kelapang, dan pengambilan sample. Peta dasar dikoreksi berdasarkan hasil pengamatan lapang, dan selanjutnya dibuat peta sebaran lahan berdasarkan tingkat produktivitasnya sebagai penghasil biomassa. Hasil penelitian menunjukkan bahwa luas penghasil biomassa, selain kawasan hutan konservasi, pemukiman, dan tubuh air di Kabupaten Lombok Barat adalah 96.050,43 ha atau 91,13\% dari luas wilayah secara keseluruhan 105.392,00 Ha. Secara keseluruhan, tingkat kerusakan lahan berdasarkan produksi biomassa di Kabupaten Lombok Barat yang tergolong sangat baik dan baik (produktif) sebagai penghasil biomasa masing-masing adalah 27,21 ha dan 30,026 ha $(57.236$ ha/54 \%), tingkat kerusakan lahan yang tergolong sedang dan buruk masing-masing adalah 38,389 ha dan 9,205 ha (47.594 ha/45\%), dan tingkat kerusakan lahan yang tergolong sangat buruk (tidak produktif sebagai penghasil biomasa) hanya seluas 561.21 ha $( \pm 1 \%)$.

\begin{tabular}{ll}
\hline Key words : & Abstract \\
\hline Land damage, & The purpose of this research is to know the level of land damage in West Lombok, \\
Biomass & especially related to the land ability for biomass production, Research was done using a \\
& survey method. First work conducted by making a basic map (scale $1: 50,000$ ) using Alos \\
& Avnir-2 satellite figure as a temporary map which was then overlaid with topograpic and \\
& landuse map, and continued with determining the sampling site, checking the real land \\
condition (field checking), and samplies collection. Basic map was corrected based on field \\
observation, continued with making land distribution map based on the level of productivity \\
of biomass production. Research showed that the area of biomass production, excluding the \\
forest conservation area, housing, and water body in the West Lombok District was \\
96,050.43 ha or $91.13 \%$ from the total area of $105,392.00$ Ha. Overall, the level of land \\
damage based on biomass production in West Lombok District that can be categorized as \\
very good and good as biomass production was respectively 27,21 ha and 30,026 ha (57.236 \\
ha/54 \%), medium and worse category was 38,389 ha and 9,205 ha respectively (47,594 \\
Ha/45\%), and the worst level of land damage (non-productive biomass production) was \\
only 561.21 Ha $( \pm 1 \%)$.
\end{tabular}




\section{PENDAHULUAN}

Upaya perbaikan kondisi lingkungan melalui program Rehabilitasi Hutan dan Lahan (RHL) akan dapat terlaksana dengan baik apabila informasi obyektif kondisi hutan dan lahan sasaran RHL tersedia. Penyediaan data dan informasi tersebut sangat diperlukan terutama dalam menyusun strategi RHL yang berdayaguna, sehingga dapat diperoleh hasil pelaksanaan RHL yang optimal dengan kondisi lingkungan kawasan hutan dan lahan sekitarnya yang dapat berfungsi optimal sesuai dengan kemampuan daya dukungnya serta kondisi sosial ekonomi dan budaya masyarakat. Aktivitas penduduk yang terkait baik langsung maupun tidak langsung dengan lahan akan mempengaruhi perubahan kondisi lahan. Dengan demikian, penyusunan kebijakan penggunaan lahan yang tepat didasarkan dari hubungan dan interaksi antara manusia dan lingkungannya yaitu lahan ( $\mathrm{Lu}, 2003$ )

Pada akhir-akhir ini, tinjauan mengenai kondisi kerusakan lahan lebih dikaitkan pada aspek lingkungan khususnya masalah perubahan iklim atau pemanasan global. Untuk itu Kerusakan lahan (land degradation) serta pengendaliannya difokuskan pada fungsi tanah sebagai penghasil/produsen biomassyang merujuk kepada penurunan kapasitas lahan bagi produksi atau penurunan potensi bagi pengelolaan lingkungan dengan kata lain penurunan mutu lahan (Pieri at al., 1995).

Ketersediaan informasi yang akurat dan informatif mengenai luasan dan sebaran lahan sesuai dengan tingkat kerusakannya mempunyai arti yang sangat penting.Updating data kerusakan dan kekeritisan lahan harus terus dilakukan. Pengunaan teknologi penginderaan jauh dan sistem informasi geografi memberikan kemudahan dalam updating informasi sumberdaya lahan. Beberapa penelitian tentang updating penyediaan data sumberddaya lahan tersaji dalam; Land-use and land-cover (LULC) change Tappan et al. 2000, Zhan et al. 2000, Kaufmann and Seto 2001, Zomer et al. 2001, Lunetta et al. 2002, Sitorus at al, 2006).

Salah satu hasil pengembangan teknologi pengindraan jauh yang mampu menyediakan data spasial adalah satelit ALOS (Advanced Land Observing Satellite). Sensor AVNIR-2 yang memiliki resolusi spasial 10 meter mampu melakukan pengamatan permukaan lahan lebih detil misalnya mengenai tingkat kerapatan dan jenis vegetasi (Sitanggang, 2007). Karakteristik citra AVNIR-2 ini dapat memberikan kontribusi yang penting dalam penyediaan data yang terkait dengan informasi vegetasi dan sumberdaya lahan.

Tujuan penelitian ini adalah mengetahui sebaran dan luasan kondisi (tingkat kerusakan) lahan di Kabupaten Lombok Barat pada Tahun 2013, khususnya yang berkaitan dengan kemampuan lahan dalam memproduksi biomasa, menyusun peta tingkat kerusakan lahan sebagai media informasi secara cepat, menyusun rekomendasi dalam pengambilan keputusan/ kebijakan Rehabilitasi Lahan dan Konservasi Tanah (RLKT) di Kabupaten Lombok Barat.

\section{METODOLOGI PENELITIAN}

Penelitian ini dilakukan dengan cara dan tahapan sebagai berikut:

1. Identifikasi Kondisi Awal Tanah

Identifikasi kondisi awal tanah dilakukan dengan tujuan untuk mengetahui areal yang berpotensi mengalami kerusakan, yaitu dengan:

a. Menghimpun data sekunder untuk memperoleh informasi awal sifat-sifat dasar tanah yang terkait dengan parameter kerusakan tanah. Peta tanah dan peta lahan kritis biasanya memuat informasi sifat dasar tanah.

b. Menghimpun data sekunder yang terkait dengan kondisi iklim, topografi, penggunaan tanah, dan potensi sumber kerusakan.

c. Menghimpun data sekunder lain yang dapat mendukung penetapan kondisi tanah, seperti citra satelit, data kependudukan dan sosial ekonomi masyarakat.

d. Membuat peta tematik terhimpun dari data sekunder dengan skala minimal 1:100.000.

e. Melakukan overlay peta tematik yang telah dibuat guna memperoleh gambaran tentang areal yang berpotensi mengalami kerusakan tanah.

f. Menentukan lokasi pengambilan sampel untuk melakukan verifikasi kerusakan tanah.

2. Evaluasi Untuk Penetapan Status Kerusakan Tanah

Setelah dilakukan identifikasi kondisi awal tanah, analisis sifat dasar tanah, selanjutnya 
dilakukan evaluasi. Evaluasi ini bertujuan untuk menentukan rusak tidaknya suatu lokasi tanah berdasarkan kriteria baku kerusakan tanah. Evaluasi dilakukan dengan membandingkan hasil analisis sifat dasar tanah berdasarkan kreteria baku kerusakan tanah. Apabila salah satu ambang parameter terlampaui, maka tanah dikatakan rusak.

Selanjutnya hasil evaluasi ini digunakan untuk menetapkan status kerusakan tanah dengan melakukan:

a. Analisis citra ALOS AVNIR-2 untuk mendapatkan peta Kerapatan Vegetasi sebagai parameter penutup lahan (land coverage). Proses yang dilakukan meliputi koreksi citra yang dilanjutkan dengan klasifikasi kerapatan vegetasi dengan metode maximum likelihood.

b. Melakukan overlay peta tutupan lahan dengan peta penggunaan lahan, peta lereng, peta jenis tanah dan peta curah hujan.

c. Berdasarkan hasil overlay peta diperoleh peta tingkat kekritisan/produktivitas biomassa. Hasil ini masih bersifat sementara (hasil pekerjaan studio). Selanjutnya, ditentukan lokasi pengecekan ke lapangan (ground check) dan sampling, terutama untuk wilayah yang tergambar dalam unit-unit peta dengan tingkat 'kritis' atau 'kurang produktif' sebagai penghasil biomas sampai dengan 'sangat kritis' atau 'tidak produktif sama sekali'. Di lokasi sampling yang telah ditetapkan dilakukan observasi dan wawancara kondisi sosial ekonomi penduduk.

d. Hasil pengecekan lapang, dipadukan dengan data hasil analisis laboratorium, kemudian dipetakan sehingga dihasilkan peta distribusi tingkat kerusakan lahan atau tingkat produktivitas biomassa.

\section{HASIL DAN PEMBAHASAN}

1. Kerusakan Lahan dan Produksi Biomassa.

Berdasarkan peta Tataguna Lahan 2013 wilayah Lombok Barat,dengan luas keseluruhan 105.392,00 Ha, terdiri atas berbagai macam penggunaan lahan, yang meliputi kawasan hutan, kawasan budidaya, mangrove, tambak/empang, dan lain-lain. Lahan dengan berbagai penggunaannya tersebut merupakan lahan penghasil biomasa. Hasil evaluasi tingkat kerusakan lahan sebagai produsen biomassa disajikan pada Tabel 1 .

Tabel 1. Luas lahan (ha) di Kabupaten Lombok Barat Tahun 2013 berdasarkan jenis penggunaannya dan tingkat kerusakan atau produktifitasnya sebagai penghasil biomassa.

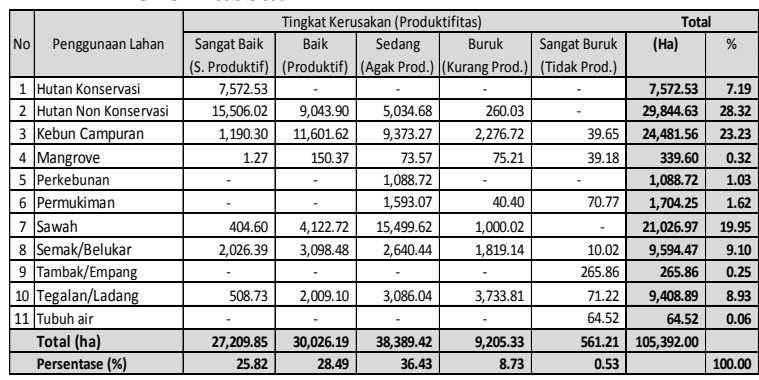

Berdasarkan Tabel 1 di atas, maka dapat dihitung luas lahan penghasil biomassa di Kabupaten Lombok Barat, yaitu total luas Kabupaten Lombok Barat dikurangi dengan luas hutan konservasi, luas pemukiman, dan luas tubuh air $=96.050,43$ ha atau 91,13\%dari luas wilayah daratan Kabupaten Lombok Barat.

Masing-masing penggunaan lahan memiliki tingkat produksi biomassa yang berbeda-beda, sebagaimana yang disajikan dalam Tabel 1. Berdasarkan Tabel tersebut dapat dilihat bahwa tingkat produksi biomassa masing-masing penggunaan lahan ternyata cukup beragam, mulai dari sangat produktif sampai dengan tidak produktif. Namun hutan konservasi seluruhnya masih memiliki tingkat produksi biomassa yang tinggi.

Secara keseluruhan, tingkat kerusakan lahan berdasarkan produksi biomassa di Kabupaten Lombok Barat disajikan pada Gambar 1. Pada gambar tersebut dapat dihitung bahwa yang tergolong sangat baik dan baik (produktif) sebagai penghasil biomasa masingmasing adalah 27,21 ha dan 30,026 ha $(57.236$ ha $/ 54 \%)$. Tingkat kerusakan lahan yang tergolong kreteria sedang dan buruk masingmasing adalah 38,389 ha dan 9,205 ha (47.594 ha/45 \%) serta tingkat kerusakan lahan yang tergolong kreteria sangat buruk (tidak produktif sebagai penghasil biomasa) seluas 561,21 ha ( \pm 1 $\%)$.

Jika luas kreteria kerusakan lahan "buruk dan sangat buruk" dijumlahkan maka didapatkan luas 9.766,21 ha (10\%). Melihat data tersebut dapat dikatakan bahwa $10 \%$ dari luas lahan di Kabupaten Lombok Barat sudah mengalami kerusakan sedangkan luas lahan 
yang sudah mulai mengalami penurunan produktifitas dalam memproduksi biomassa seluas 38.389 ha $(36 \%)$ yaitu dengan kreteria "kerusakan sedang". Kondisi ini harus mendapat perhatian yang serius dari pemerintah dan masyarakat untuk antisipasi peningkatan luas kerusakan lahan di Kabupaten Lombok Barat.

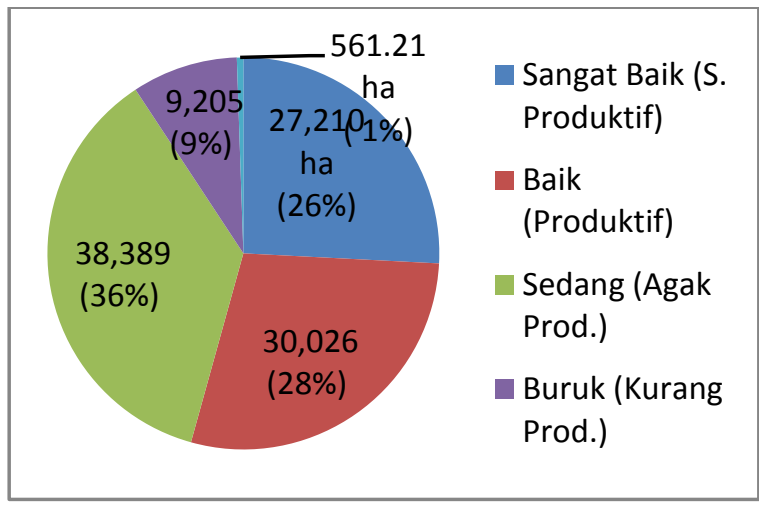

Gambar 1. Persentase tingkat kerusakan lahan untuk produksi biomassaDi Kabupaten Lombok Barat.

Sebaran tingkat kerusakan lahan dari kreteria sangat baik, sampai kreteria sedang tampaknya tersebar merata di seluruh wilayah Kabupaten Lombok Barat (Tabel 2). Sebaran tingkat kerusakan lahan kreteria buruk sampai kreteria sangat buruk hanya terjadi di Kecamatan Lembar dan Sekotong Tengah. Oleh karena kedua kecamatan tersebut memiliki tingkat kerusakan lahan yang serius (kritis), maka program kegiatan rehabilitasi lahan pada kedua wilayah kecamatan tersebut harus diprioritaskan untuk menghindari dampak yang merugikan bagi penduduk yang mengelola lahan di wilayah tersebut.

Tabel 2. : Luas Lahan/Tanah Untuk Produksi Biomassa Pada Setiap Kecamatan di Kabupaten Lombok Barat.

\begin{tabular}{|c|c|c|c|c|c|c|c|c|}
\hline \multirow[b]{2}{*}{ No } & \multirow[b]{2}{*}{ KECAMATAN } & \multicolumn{5}{|c|}{ Tingkat Kerusakan (Produktifitas) } & \multicolumn{2}{|c|}{ Total } \\
\hline & & \begin{tabular}{|c|} 
Sangat Baik \\
(S. Produktiff \\
\end{tabular} & $\begin{array}{c}\text { Baik } \\
\text { (Produktif) }\end{array}$ & \begin{tabular}{|c|} 
Sedang \\
(Agak Prod.)
\end{tabular} & \begin{tabular}{|c|} 
Buruk \\
(Kurang Prod.)
\end{tabular} & \begin{tabular}{|l|} 
Sangat Buruk \\
(Tidak Prod.). \\
\end{tabular} & (Ha) & $\%$ \\
\hline 1 & BATU LAYAR & 372.78 & $1,849.19$ & $1,189.04$ & - & - & $3,411.00$ & 3.24 \\
\hline 2 & GERUNG & $1,372.60$ & 223.57 & $4,633.83$ & - & - & $6,230.00$ & 5.91 \\
\hline 3 & GUNUNG SARI & $3,161.64$ & $3,858.90$ & $1,953.46$ & - & - & $8,974.00$ & 8.51 \\
\hline 4 & KEDIRI & & 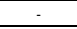 & $2,164.00$ & - & - & $2,164.00$ & 2.05 \\
\hline 5 & KURIPAN & 504.71 & - & $1,651.29$ & - & - & $2,156.00$ & 2.05 \\
\hline 6 & LABU API & 16.96 & & $2,816.04$ & - & - & $2,833.00$ & 2.69 \\
\hline 7 & LEMBAR & 970.09 & 637.17 & $3,278.89$ & $1,379.84$ & - & $6,266.00$ & 5.95 \\
\hline 8 & LINGSAR & $5,166.19$ & $2,807.83$ & $1,683.98$ & - & - & $9,658.00$ & 9.16 \\
\hline 9 & NARMADA & $6,172.14$ & $3,480.23$ & $1,109.63$ & - & - & $10,762.00$ & 10.21 \\
\hline & SEKOTONG & $9,472.73$ & $17,169,30$ & $17,909.26$ & $7,825.49$ & 561.21 & $52,938.00$ & 50.23 \\
\hline & TOTAL & $27,209.85$ & $30,026.19$ & $38,389.42$ & $9,205.33$ & 561.21 & $105,392.00$ & 100.00 \\
\hline
\end{tabular}

Persentase Tutupan Lahan. Dalam kriteria tersebut pada Tabel 2, rendahnya persentase penutupan lahan oleh vegetasi (kanopi untuk kawasan hutan) merupakan faktor pembatas sangat penting sebagai indikator tingkat produksi biomasa, mempunyai bobot 50 $\%$ dalam menentukan tingkat kerusakan lahan. di Kabupaten Lombok Barat yang termasuk kreteria buruk sampai dengan sangat buruk. Kondisi itu umumnya dibarengi dengan faktor kelerengan (lereng curam) yang berdampak pada tingkat erosi potensial maupun aktual yang tinggi.

Berdasarkan pengecekan dan wawancara di lapangan, munculnya kerusakan lahan diakibatkan oleh ulah manusia (masyarakat) terutama adalah (1) penebangan hutan secara liar oleh oknum tak bertanggung jawab yang terjadi terutama pada periode 2000 2004, dan (2) peladangan berpindah yang hingga sekarang masih banyak terjadi terutama di Kecamatan Sekotong. Hal ini terkait dengan luas lahan yang cukup luas mengalami kerusakan di Kecamatan Sekotong yaitu 7.825,49 Ha (Tabel 2) untuk kreteria produktivitas buruk.

Berkaitan dengan masalah dan faktor penyebab terjadinya lahan kritis tersebut di atas, maka perlu dilakukan tindakan pencegahan dan pemulihan kondisi vegetasi penutup lahan yang sudah rusak. Tindakan teknis yang umumnya direkomendasikan untuk mengatasi masalah itu adalah reboisasi (untuk kawasan hutan), optimasi pemanfaatan lahan terlantar dengan kegiatan usahatani, meningkatkan pemanfaatan sumber air yang ada untuk usahatani lahan kering, dan sebagainya (Suwardji dan Tejowulan). Tindakan non teknis dilakukan melalui perbaikan management, pendekatan sosial-budaya, misalnya menyadarkan dan memberikan pengertian kepada masyarakat terhadap pentingnya kelestarian hutan lindung maupun lahan usahatani. Yang tidak kalah pentingnya, bahkan sering menjadi faktor penyebab utama munculnya ulah sebagian anggota masyarakat (peladang liar) yang berakibat pada peningkatan kerusakan kawasan hutan menjadi lahan terbuka dan terdegradasi, adalah kondisi ekonomi masyarakat di sekitas hutan yang sangat memprihatinkan, dan terbatasnya lapangan pekerjaan di sektor non pertanian. Mereka umumnya terpaksa membabat hutan di kawasan lindung untuk bertani karena tidak mempunyai pilihan lain untuk dapat memenuhi kebutuhan pokok sehari-harinya. Jadi, tindakan pencegahan (preventif) maupun pemulihan kondisi lahan secara teknis harus 
dibarengi dengan upaya peningkatan kesejahteraan masyarakat terutama yang berada di sekitar kawasan hutan.

Produktivitas Lahan. Berdasarkan hasil analisis overlay peta sebaran kerusakan lahan yang tersaji pada Gambar 2, untuk kreteria sedang umumnya tersebar di penggunaan lahan sawah. Pada penggunaan lahan sawah terjadi pengelolaan tanah secara intensif sifat ini mempengaruhi tingkat kerusakan tanah. Di lahan sawah beririgasi umumnya ditanami sangat intensif ( $3-4$ kali setahun), sedangkan lahan kering, lahan sawah tadah hujan, umumnya ditanami hanya 2 kali, bahkan yang sumber airnya hanya dari air hujan hanya dapat ditanami sekali setahun, sehingga produktivitas biomasanya kreterianya rendah - sangat rendah.

Kemiringan Lereng. Berdasarkan pembobotan overlay peta kemiringan lereng terhadap hasil analisis kerusakan lahan menunjukan bahwa sebaran kemiringan kerusakan lahan kreteria buruk terjadi pada kemiringan lereng tinggi yaitu $15-25 \%$ dan $25-$ $40 \%$ dimana sebaran kreteria buruk banyak tersebar di kecamatan sekotong.

Management. Wawancara dengan Faktor management (pengelolaan) yang sudah ada atau sudah diterapkan, mempunyai andil terhadap produktivitas lahan dalam menghasilkan biomasa. Termasuk dalam faktor management, selain meliputi aspek teknis (agrononis) pada lahan usahatani, juga pengelolaan untuk konservasi lahan dan hutan meliputi aspek sosial-budaya, pembinaan masyarakat di sekitar kawasan hutan (Jatmiko at al., 2012)

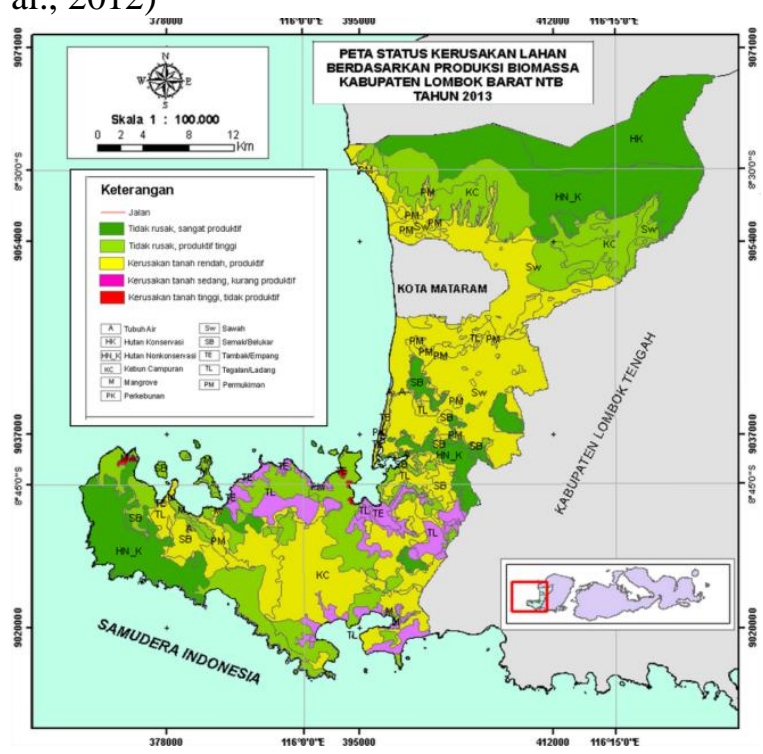

Gambar 2. Peta Status Kerusakan Lahan berdasarkan produksi biomassa di Kabupaten Lombok Barat Tahun 2013

\section{KESIMPULAN}

1. Kerusakan lahan untuk produksi biomassa di Kabupaten Lombok Barat masing relatif rendah yaitu kreteria rusak dan sangat rusak seluas $9.766,21$ ha (10\%).

2. Luas lahan dengan kondisi baik atau kreteria sangat produktif dan sangat produktif sebagai penghasil biomasa masing- masing 30,026 ha dan 27,21 ha atau seluruhnya 57.236 ha $(54 \%)$.

3. Kerusakan lahan untuk produksi biomassa dengan kreteria kerusakan sedang tersebar pada penggunaan lahan sawah dan ladang, sedangkan penggunaan lahan untuk hutan masih dalam kondisi baik yaitu masih pada kreteria produktif sampai kreteria sangat produktif untuk produksi biomassa.

\section{DAFTAR PUSTAKA}

Anonim (2005). PP. N0.150 Thn.2000. Tentang Pengendalian Kerusakan Tanah Untuk Produksi Biomassa. Kementerian Negara Lingkungan Hidup.

Anonim (2006). Permeneg LH No.07 Tahun 2006. Tentang Tata Cara Pengukuran Kriteria Baku Kerusakan Tanah Untuk Produksi Biomassa. Kementerian Negara Lingkungan Hidup.

Anonim (2008). Permeneg LH No. 19 Tahun 2008. Tentang Standar Peleayanan Minimal Bidang Lingkungan Hidup Daerah Provinsi dan Kementerian daerah Kabupaten/Kota.

Anonim (2008). Permeneg LH No. 20 Tahun 2008. Tentang Petunjuk Teknis Standar Pelayanan Minimal Bidang Lingkungan Hidup Daerah Provinsi dan Daerah Kabupaten/Kota.

Direktorat Jendral Reboisasi dan Rehabilitasi Lahan (1998). Pedoman Penyusunan Perencanaan Teknik Lapangan Rehabilitasi Lahan dan Konservasi Tanah Daerah Aliran Sungai. Jakarta 129hal.

FAO (1977). A framework for land evaluation. ILI Wageningen 87 hal.

FAO (1984). Land resources evaluation with emphasis on the outher islands. 
Indonesia Terminal Report UNDPFAO. Rome 55 hal.

Lu, D, P. Mausel at all, Change Detection Techniques, International J. Remote Sensing, Jun 2004, Vol 25, No 12, P.2365 -2407.

Pieri, CH., J. Dumanski, A. Hamblin, dan A. Young (1995). Land quality indicators.

World Bank Discussion Paper. The World Bank Washington DC. 63 hal.

Sitanggang, G. 2007. Sistem Pengindraan Jauh Satelit ALOS dan Analisis Pemanfaatan Data. Majalah sains dan Teknologi Dirgantara Vol.2.No.2.

Sitorus, S.R.P. (1985). Evaluasi sumberdaya lahan. Penerbit Transito Bandung.

Sitorus, Jansen dkk, 2006. Kajian Model Deteksi Perubahan Penutup Lahan Menggunakan Data Inderaja Untuk Aplikasi Perubahan Lahan Sawah. Bidang Pengembangan Pemanfaatan Inderaja Pusbangja Lapan.

Suwardji dan Tejowulan (2003). Lahan kritis dan lingkungan hidup. Makalah Seminar Nasional Lahan Kritis di Universitas Muhammadiyah Mataram. 10 hal.

Watson, R.T. (2000). Land Use, Land-Use Change, and Forestry. Cambridge University Press. 377 hal. 